\title{
Documenting the complex relationship between self-efficacy, resiliency, and workplace empowerment: a case study of humanitarian workers in Palestine
}

\author{
Jess Bonnan-White ${ }^{*}$ (iD and Ameena Issa
}

\begin{abstract}
There remains a critical gap in understanding challenges faced by humanitarian workers who may be key in providing assistance during complex emergencies. This study examines self-reported views by humanitarian workers working in Palestine concerning three concepts: resilience, generalized self-efficacy, and importance of workplace empowerment. Aid workers in Palestine face unique obstacles placed on economic, social, and political autonomy imposed by Israeli policy. Data obtained from 46 humanitarian workers recruited using snowball sampling methodology hint at a complex relationship between the three concepts. Firstly, a hypothesized positive relationship between resiliency and generalized self-efficacy was supported. Secondly, an unexpected negative relationship was found between resiliency and workplace empowerment. Finally, counter to our hypothesis, no significant relationship was found between self-efficacy and workplace empowerment. Gender differences also highlight disparities between the experience of women and men in the non-profit workplace in Palestine. This study adds to our knowledge regarding unique stresses on humanitarian workers and enhances a growing base of literature focused on national staff and volunteers.
\end{abstract}

\section{Background}

Following a natural, man-made, or technological disaster, local disaster relief and development staff workers (referred to herein as humanitarian workers) act as vital linkages in the disaster relief chain. The UN Office for Disaster Risk Reduction (UNISDR) (UNISDR 2009) defines disaster as "a serious disruption of the functioning of a community or a society involving widespread human, material, economic or environmental losses and impacts, which exceeds the ability of the affected community or society to cope using its own resources" (emphasis added). In 2015, a technical paper facilitated by UNISDR suggested amending the definition to read, "a serious disruption of the functioning of the community or society due to hazardous events interacting with conditions of vulnerability and exposure, leading to widespread human, material, economic and environmental losses and impacts" (emphasis added) (UNISDR 2015). In both of these

* Correspondence: Jess.Bonnan-White@stockton.edu Stockton University, Galloway, NJ, USA definitions, humanitarian workers play a prominent role, both as critical community resources that can be called upon in emergencies, and as a source of vulnerability should those workers not be provided sufficient physical, emotional, or technical support. In the present paper, humanitarian workers are examined as critical assets that should be considered assessing how community resources are overwhelmed during periods of emergency.

In the USA, emergency management practitioners and scholars continue to refine preparedness, response, and recovery procedures so that key assets of the community are recognized as part of disaster relief or humanitarian assistance supply chains. Thus, the prominent role of humanitarian agencies and social aid groups is evident in both the Department of Homeland Security (DHS) National Response Framework and the National Disaster Recovery Framework (DHS 2011, 2013). Their inclusion represents the value of the whole community in emergency response, including individuals, the private sector, non-governmental and non-profit organizations, faith- 
based and community organizations, and all levels of government (local, state, and federal) (DHS 2015). In particular, non-profit, non-governmental, faith-based, and community organizations play a key humanitarian role in emergencies, providing survival resources (shelter, clothing, food, water, sanitation, and health care), supporting evacuation and family reunification, training volunteer resources, and identifying unmet needs (DHS 2013).

Research on the efficacy of humanitarian supply chains has, in recent years, intensified due partly to the increasing human and monetary cost of natural disasters and conflict. Considerable attention has focused on challenges impacting relief chain structures, including maintaining humanitarian space, mobilizing suppliers, meeting donor interests, coordinating transportation resources, and organizing local distribution activity (e.g., Kleinfeld 2007; Kovacs and Spens 2007; de Silva 2009; Balcik et al. 2010; Hilhorst and Jansen 2010; da Costa et al. 2014). Others have examined factors impacting humanitarian service delivery, including coordination difficulties, issues arising with disconnection between humanitarian needs and donor demands, and the relationship between the public and private sector (Simo and Bies 2007; Balcik et al. 2010).

Relatively less research emphasis concentrates on factors impacting human actors delivering humanitarian service. Valuable work previously highlighted stresses experienced by expatriate (international) workers employed by nongovernmental organizations (NGOs) to deliver humanitarian aid or facilitate development projects (Ehrenreich and Elliott 2004; Eriksson et al. 2013). Others have isolated experiences of in-country (national) field workers challenged with balancing donor and organizational demands with localized conditions and power structures (Suparamaniam and Dekker 2003; Lopes Cardozo et al. 2005; Shah et al. 2007; Musa and Hamid 2008). In complex emergencies, communities already confronting prolonged military conflict, social upheaval, and economic and social deprivation face additional obstacles in receiving humanitarian aid (Lucchi 2010). In the present study, we concentrate on selfreported levels of resiliency, generalized self-efficacy, and perception of workplace empowerment in a sample of humanitarian workers working in a long-term complex emergency.

The subjects of the present study are humanitarian workers working in an area referred variably to as the State of Palestine or the occupied Palestinian territories (oPt). As a modern political entity, the statehood of Palestine was first asserted in 1988, following decades of contestation following the dissolution of the Ottoman Empire following World War I. Statehood was more recently re-enforced in 2012 as it was granted "non-member observer state" status by the United National General
Assembly (United Nations, 2012). Since 1967, however, the discontinuous geographic areas of Palestine (including the Gaza Strip, West Bank, and East Jerusalem) have been under military occupation or control by Israel. In January 2015, the State of Palestine accepted the Rome Statute of the International Criminal Court (ICC) and, accordingly, ICC jurisdiction. Although beyond the immediate scope of the paper, the humanitarian and legal implications of defining the occupation and obligations under international law have been presented in a variety of forms (e.g., Cohen and Arieli 2005; Droege 2007; Gross 2007; Darcy and Reynolds 2010; Kretzmer 2012; Greenblatt 2014). Throughout the present paper, therefore, the term "Palestine" will be utilized in reference to the most recent United Nations and International Criminal Court recognized designations of the occupied Palestinian territories (Gaza Strip, West Bank, and East Jerusalem).

Palestine was chosen as the study site for several reasons. Firstly, the authors were familiar with the area, not only as a resident (second author) but also through research conducted by the authors in the northern West Bank (Bonnan-White et al. 2013). Secondly, living conditions continue to deteriorate in Gaza, the West Bank, and occupied East Jerusalem since the Oslo Peace Accords $(1993,1995)$. According to the most recent available support by the UN Office for the Coordination of Humanitarian Affairs (December, 2015), the unemployment rate in Gaza was 42.7 \%. At the same time, Gaza faces an ongoing Israeli blockade of critical goods and services, including the limits on fishermen and farmers accessing farmland and fishing waters within territorial borders. In 2015, the average number of truckloads of exported goods leaving Gaza stood at less than $10 \%$ of 2007 levels (OCHA 2015b). Following the 2014 conflict, approximately 95,000 people in Gaza remain displaced. In the West Bank, the International Monetary Fund reports the unemployment rate to be $15.4 \%$. Like Gaza, West Bank communities struggle with checkpoints [fixed and "flying" (temporary) limiting free travel within and out of the West Bank borders (B’Tselem 2015)]. Additionally, in the West Bank, residents live with threat of forcible transfer from their homes or home demolition (UNOCHA 2016).

Finally, the authors were present in Nablus during a period of extreme winter weather and flash flooding during January 2013 (Taha et al. 2014). During this period, residents of the area were killed as a result of the flooding; in the process, the community struggled with conflicting reports of their death, safe recovery, and identification (Ma'an 2013a, b, c). Reports of the flooding from Gaza and in Syrian refugee camps in Lebanon and Jordan also distressed West Bank residents (Ma'an 2013d, e), and the authors observed that questions arise in public conversations about local capacities to respond to such large-scale events. 
Currently, the most outward signs of Israeli control over Palestinian areas include an economic and supply blockade of the Gaza Strip, construction of a Security Wall largely on Palestinian territory, support by Israel for the construction of settler communities within the West Bank, and a series of permanent and temporary checkpoints and roadblocks that largely serve to isolate Palestinian communities. Each of these not only present challenges to international law but they also present external occupational hazards and professional barriers humanitarian staff and volunteers. For example, the United Nations Office for the Coordination of Humanitarian Affairs (OCHA) in Palestine reported 110 settler-related incidents that lead to Palestinian fatalities in 2014, with 221 incidents resulting in damage to Palestinian property (OCHA 2015a). Humanitarian staff reported a monthly average of 29 incidents of delay at checkpoints in 2014, and a monthly average loss of 25 staff days (OCHA 2015a). Emergency medical workers have also experienced prolonged waits at checkpoints and border crossings, delaying treatment of the critically ill and wounded (Rytter et al. 2006).

A rich body of literature documents the impact of chronic conflict, violence, humiliation, and imprisonment on Palestinian social institutions, family function, personal coping mechanisms, and development of social support networks (see Khamis 1993; Punamäki et al. 2002, 2005; Kanninen et al. 2003; Giacaman et al. 2004; Roy 2004; Peltonen et al. 2010; Hobfall et al. 2012 for examples). It should come as no surprise that levels of stress, anxiety, and trauma symptomology are elevated in Palestinian populations living in both West Bank and Gaza Strip communities who are exposed to armed conflict and violence (de Jong et al. 2003; Giacaman et al. 2007; Khamis 2008; Qouta et al. 2008). First responders, volunteers, and development workers, particularly those recruited from the local Palestinian communities, not only assist survivors of conflict but may also themselves be survivors ("survivor-helpers") (Cronin et al. 2007; Baum 2014). Threat of violence to Palestinian medical workers (including ambulance staff, nurses, and doctors) is a particular concern (Rubenstein and Bittle 2010). During the June-August 2014 Gaza hostilities, both local (Palestinian Red Crescent Society 2014) and international bodies (Office for the Coordination of Humanitarian Affairs 2014; International Committee of the Red Cross, 2014) documented violence aimed at Palestinian medical workers. In a sample of 1130 nurses working in Gaza, Alhajjar (2014) reported that $69.4 \%$ showed evidence of posttraumatic response (including intrusion, avoidance, and hyper-arousal). Palestinian social workers also demonstrate trends in negative mental health outcomes similar to those reported in other samples of social workers engaging survivors of disaster and conflict (Adams et al. 2006; Ramon et al. 2006; Baum 2014). For example, Veronese (2012) reported that quality of life was largely associated with mental health as a safety and security concern in Palestinian social workers in Tulkarm. There remains a critical gap in understanding challenges faced by broad categories of workers in "helping professions" who may be key in providing assistance during complex emergencies.

The Civil Defense Law No. 3, introduced in 1988, governs strategies for disaster response in Palestine (DCAF 2008). The Palestine Civil Defense Directorate is responsible for fire fighting, building public shelters, medical response, search and rescue, and training civilians. Strengthening disaster response through designing capacity-building programs, increasing community awareness, and establishing public safety protocols was noted as a strategic goal in the Security Sector Strategy Summary released by the Palestinian Ministry of Interior in 2014. As noted by the UN Disaster Assessment and Coordination (UNDAC) mission to Palestine (2014), the Civil Defense Law No. 3 provisions largely address Cold War era concerns with response to military, biological, chemical, and radioactive attack on civilian populations. The mission report also notes the significance of the non-governmental sector in providing emergency response and humanitarian assistance. The reliance on the non-governmental sector is due, in part, to financial and import restrictions placed on the Palestinian Authority (UNDAC 2014). In addition to over 100 national Palestinian non-governmental organizations active in the West Bank and Gaza Strip (PNGO Net 2015), major international bodies (e.g., World Vision, Oxfam International, CARE International, International Committee of the Red Cross, UNICEF, American Near East Refugee Aid, and Médecins Sans Frontières) also provide a combination of emergency relief and socioeconomic development assistance.

Humanitarian workers frequently experience stress, violent working conditions, exposure to traumatic events, and interaction with survivors as a job condition (McCall and Salama 1999). For example, among humanitarian workers in Columbia, Vergara and Gardner (2011) found that increased psychological well-being was related to cognitive hardiness, satisfaction with levels of social support, use of problem-solving coping mechanisms, and less negative appraisal. In another case, Pigni (2014) reports emotional exhaustion exhibited by Palestinian staff who not only endure the trials of the military situation in the area themselves (as community members) but also face continual turnover of managers and conflict within field teams (as staff members). These previous examples demonstrate the importance of focusing on factors that could erode perceptions of self-efficacy and resiliency and, in turn, impact the ability to flourish in a work environment. Based on the work by Bandura (1977), the first concept, self-efficacy, has been suggested 
to affect (1) how employees establish personal goals, (2) how employees engage with learning opportunities, (3) how much effort is spent on job-related activities, and (4) how employees approach new or challenging tasks (Lunenburg 2011). The second concept, resiliency, is not equivalent to recovery; instead, as explained by Bonanno (2008: 102), "resilience reflects the ability to maintain a stable equilibrium." Resilient individuals may not necessarily return to the same level of functioning following an event, but they exhibit an internal capacity for adaptation to a "new normal." Naturally, for humanitarian workers, a new normal would also include the sustained ability to contribute to workplace goals.

Self-efficacy is one of four factors (meaning, competence (self-efficacy), self-determination (choice), and impact) used to assess the development of intrinsic motivation and levels of empowerment (Thomas and Velthouse 1990; Frymier et al. 1996). Beyond a personal assessment of motivation in the professional workplace, humanitarian workers may also draw meaning from their internal sense of the impact their work has on communities. This means, however, that negative experiences (for example, "moral stress") may arise from conflict with supervisory staff regarding beneficiary needs, organizational goals, and ambiguity of positive impact on beneficiaries (de Waal 2010; Nilsson et al. 2011). For Palestinians, impact and meaning may not only be related to providing community benefit but also how effort relates to the longer history of Palestinian struggle against a colonial settler-regime growing in power since the late 1800s (Fast 2006; Shalhoub-Kevorkian 2015). Secondly, we examine how these two constructs may be related to feelings of impact and meaningfulness in the humanitarian workplace environment.

Using the theoretical framework proposed, the present study was initiated with the following predictions regarding the relationship between resiliency, workplace empowerment, and generalized self-efficacy:

- H1: There will be a positive correlation between resiliency and generalized self-efficacy.

- H2: Levels of reported importance (saliency) of workplace empowerment concepts (impact and meaningfulness) will be positively related to resiliency and self-efficacy.

\section{Methods}

An online survey instrument was designed incorporating four different elements: the Generalized Self-Efficacy Scale (GSE), the Self-Assessment of Resiliency and Anxiety (SARA), and two scales measuring the saliency of two components identified with the construct of empowerment, meaningfulness, and impact (Frymier et al 1996). Initially, the research team was concerned that survey instruments written for other cultural contexts would not be appropriate for standard back translation approaches. This concern was prompted by review of fieldwork conducted by Afana and colleagues (2010) examining variation in localized language describing experiences of trauma in Gaza. Thus, initial versions of questions were compiled in English and translated into Arabic utilizing an in-person consensus format with two native Palestinian (Levantine)-Arabic dialect speakers (including the second author) and one native English speaker (first author). The entire team wanted to utilize terminology most appropriate, in their experience, to localized practice in Palestine and using terms that might be most familiar to Palestinian-Arabic speakers (rather than relying upon a standardized Arabic translation). Our approach was used to address major concerns about standard back translation-efficacy in relating information in localized dialects, variation in team member comprehension of foreign-language terms, and representing a participatory, culturally informed process (Sumathipala and Murray, 2000; Inhetveen, 2012).

The final survey (including an option to participate in either English or Arabic) was created using Survey Monkey and distributed using a snowball sampling technique. A snowball technique was employed due to a concern regarding access and trust building between local humanitarian workers and a foreign principal investigator (first author) (Cohen and Arieli 2011). The two translation team members (both Palestinian humanitarian workers) were therefore used as distribution actors for survey. Stockton University Institutional Review Board approval was obtained in April 2014. Data were collected between May and November 2014. It should be noted that the data collection period encompassed a major Israeli military campaign directed at the Gaza Strip (July-August, 2014; "Operation Protective Edge"); with the relatively small number of participants indicating fieldwork in Gaza; however, it was difficult to compare pre- and post-campaign. Eighty-three (83) initial responses were collected; however, after deleting incomplete responses or those that were repeated following an incomplete first attempt, the final sample totaled 45 to 46 participants. Of the completed responses, 29 (63\%) responded to the Arabic instrument, 16 (34.7\%) to the English. Although the target participant audience was initially designed to be local (national) Palestinian workers, it is likely that some international (expatriate) workers may have replied despite recruitment procedures. With the percentage of respondents that chose to answer the survey in Arabic, however, we feel that data reflect largely Palestinian voices.

\section{Measures}

Demographic information

Demographic information collected represented a balance between potential comparative factors that might prove 
relevant in analysis and concern for confidentiality for participants. Given the ongoing military conflict and the fear of unnecessarily exposing participants to scrutiny, limited demographic data were obtained. For the exploratory purposes of the present study, the following demographic variables were collected: (1) gender, (2) location of fieldwork (identified by selecting 1 or more of 12 Palestinian governate designations), (3) nature of organization (international non-governmental organization, INGO; Palestinian nongovernmental organization, PNGO; governmental agency; other), and (4) years of service at current organization. In the sample, 23 (50\%) respondents had more than 5 years experience in the humanitarian sector. The majority (56.5 \%) of the respondents were employed by INGOs, whereas 17 (37 \%) worked for PNGOs. The remaining three identified as working either for the government (1) or for unidentified (1) or "other" (1) categories. Thirty-two (70\%) of the respondents reported working within one Palestinian governate. Finally, the sample was composed of 25 (54.3\%) females and 21 (45.7 \%) males.

\section{Generalized Self-Efficacy (GSE)}

Respondents were asked to answer ten questions designed by Schwarzer and Jerusalem (1995) (presented in a revised form in Schwarzer and Hallum (2008)) designed to measure perceptions of general self-efficacy. The GSE has been used in a number of different occupational and cultural contexts (Scholz et al. 2002; Luszczynska et al. 2005) and was chosen here for its attention on global functioning and sense of personal competence. Previous studies have confirmed the internal validity of the ten-item scale. For example, Luszczynska et al. (2005) obtained Cronbach's alpha scores of .94, .90, and .86 for German, Polish, and South Korean samples, respectively. In another case, Schwarzer and Hallum (2008) reported a Cronbach's alpha value of .85 in a Syrian sample. Participants in the present study were asked to answer the questions referencing their personal social life using a 4-point Likert scale $(1=$ not at all true, 4 = exactly true). Questions included, "I can always manage to solve difficult problems if I try hard enough" and "I am confident that I could deal efficiently with unexpected events" (see full range of questions in Table 1). No answers required code reversal, and summed score values had a potential range between 10 and 40 . For the present sample, strong internal consistency was also demonstrated (Cronbach's $\alpha=.883, N=46, M=33.06, \mathrm{SD}, 4.73)$. Although the Palestinian-Arabic version of the GSE utilized here is modified from that used in previous research with other Arabic-speaking respondents, its internal consistency is similarly strong (Schwarzer and Hallum 2008). Removal of any item from the present inventory would not have increased the Cronbach's value.

\section{Self-Assessment of Resilience and Anxiety (SARA)}

The eight-item SARA instrument is a participant-rated scale measuring calmness, mental clarity, confidence, resilience, social comfort, and physical well-being (Barnett et al. 2001) (Table 2). This particular scale was chosen due to its short length and established reliability and validity. Previous usage documented strong Cronbach's coefficient values $(\alpha=.825)$ (Barnett et al. 2001). The eight items were measured on a 10 -point Likert scale $(0=$ not at all, $10=$ extremely). No items required code reversal, and potential summed scores could range between 0 and 80 . The mean summative score value for the present sample was calculated at 45.84 $(N=46$, standard deviation, 14.06). A Cronbach's $\alpha$ value of .815 obtained here suggests strong internal consistency of the scale. Removal of one item (item 6) would have increased the value to .824 (an increase of .09). For the sake of comparability with previous studies, analysis of the eight original items is presented herein.

\section{Work empowerment saliency (WES) measures: importance of perceived impact and meaningfulness}

Two scales were created to measure participant's views on the importance of concepts relating to meaningfulness and

Table 1 Items measuring Generalized Self-Efficacy (GSE) employed in the present study

\begin{tabular}{|c|c|c|c|}
\hline Item statement & $N$ & Item mean & Item standard deviation \\
\hline 1. If someone opposes me, I can find the means and ways to get what I want. & 46 & 3.37 & .678 \\
\hline 2. I can always manage to solve difficult problems if I try hard enough. & 46 & 3.24 & .821 \\
\hline 3. It is easy for me to stick to my aims and accomplish my goals. & 46 & 3.24 & .603 \\
\hline 4. I can usually handle whatever comes my way. & 46 & 3.43 & .583 \\
\hline 5. Thanks to my resourcefulness, I know how to handle unforeseen situations. & 46 & 3.43 & .655 \\
\hline 6. I can solve most problems if I invest the necessary effort. & 46 & 3.46 & .622 \\
\hline 7. I can remain calm when facing difficulties because I can rely on my coping abilities. & 46 & 3.09 & .784 \\
\hline 8. When I am confronted with a problem, I can usually find several solutions. & 46 & 3.33 & .634 \\
\hline 9. If I am in trouble, I can usually think of a solution. & 46 & 3.33 & .701 \\
\hline 10. I am confident that I could deal efficiently with unexpected events. & 46 & 3.15 & .666 \\
\hline
\end{tabular}


Table 2 Items measuring Self-Assessment of Resilience and Anxiety (SARA) employed in the present study

\begin{tabular}{llll}
\hline Item statement & $N$ & Item mean & Item standard deviation \\
\hline 1. My body feels relaxed. & 46 & 4.13 & 3.000 \\
2. I feel calm. & 46 & 4.43 & 2.818 \\
3. My thoughts are focused. & 46 & 5.63 & 2.568 \\
4. I feel confident. & 46 & 6.72 & 2.248 \\
5. I am free of worries. & 46 & 4.41 & 3.166 \\
6. I feel sociable. & 46 & 7.26 & 2.294 \\
7. I do not avoid things because of fear. & 46 & 6.52 & 3.002 \\
8. I can bounce back after a stress or disappointment. & 46 & 6.74 & 1.971 \\
\hline
\end{tabular}

impact of work-related behaviors. The scales represent modified items proposed by Frymier et al. (1996) that measure student empowerment in an educational setting (Table 3). To measure the importance of meaningfulness, seven items were included from the original ten. The concept of impact was measured using 13 items from the 16 on the original instrument. These 20 items included here were chosen by the co-authors based on the authors' assessment of their applicability to a highly variable workplace environment of humanitarian workers wherein supplemental learning and training is required. Participants were asked to rate how important they felt each to be in their professional setting using a 5-point Likert scale $(0=$ not at all important, $4=$ very important $)$. No items required code reversal. Potential summed scores for the seven items of the meaningfulness scale could range between 0 and 28, whereas the values for the 13 items of the impact scale could range between 0 and 52 .

In the current sample, the average value for the 13 impact items was $17.11(N=43, \mathrm{SD}, 11.42)$. For the seven items measuring meaningfulness, the mean was $6.73(N=41, \mathrm{SD}$, 5.39). In the original instrument developed by Frymier et al. (1996), the original impact and meaningfulness scales demonstrated reliability values of .95 and .94 , respectively. Here, the modified scales composed with a subset of the original items also demonstrated strong reliability, with Cronbach's

Table 3 Items measuring saliency of workplace empowerment concepts: impact and meaningfulness

\begin{tabular}{|c|c|c|c|}
\hline Item statement & N & Item mean & $\begin{array}{l}\text { Item standard } \\
\text { deviation }\end{array}$ \\
\hline 1. I have the power to make a difference in how things are done in this organization (Impact). & 46 & 1.39 & 1.125 \\
\hline 2. I have a choice in the methods I can use to perform my work as a staff member in this organization (Impact). & 46 & 1.13 & .980 \\
\hline 3. My participation is important to the success of this organization (Impact). & 46 & .870 & .859 \\
\hline 4. I have freedom to choose among options in this organization (Impact). & 46 & 1.41 & 1.045 \\
\hline 5. I can make an impact on the way things are run in this organization (Impact). & 46 & 1.370 & 1.218 \\
\hline 6. Alternative approaches to performing my required duties are encouraged in this organization (Impact). & 45 & 1.27 & 1.136 \\
\hline 7. I have the opportunity to contribute to the learning of other staff members (Impact). & 46 & 1.26 & 1.163 \\
\hline 8. I have the opportunity to make important decisions in this organization (Impact). & 46 & 1.57 & 1.205 \\
\hline 9. I have the power to create a supportive environment in this organization (Impact). & 46 & 1.63 & 1.122 \\
\hline 10. I can determine how tasks can be performed in this organization (Impact). & 46 & 1.63 & 1.223 \\
\hline 11. I make a difference in the professional development and learning of other staff members (Impact). & 46 & 1.50 & 1.278 \\
\hline 12. I can influence the administration of this organization (Impact). & 46 & 1.48 & 1.206 \\
\hline 13. I feel appreciated in this organization (Impact). & 44 & 1.05 & 1.077 \\
\hline 14. The tasks required of me in this organization are personally meaningful (Meaningfulness). & 46 & .98 & .881 \\
\hline 15. I look forward to going to working in this organization (Meaningfulness). & 46 & 1.28 & 1.148 \\
\hline 16. This organization is exciting (Meaningfulness). & 44 & 1.14 & 1.002 \\
\hline 17. My organization is interesting (Meaningfulness). & 45 & 1.00 & .953 \\
\hline 18. The tasks required of me in this organization are valuable to me (Meaningfulness). & 46 & .76 & .900 \\
\hline 19. The information in this organization is useful (Meaningfulness). & 45 & .89 & .959 \\
\hline 20. Working in this organization will help me achieve my future goals (Meaningfulness). & 45 & 1.02 & 1.055 \\
\hline
\end{tabular}


$\alpha$ values of .91 (meaningfulness) and .95 (impact). For each scale utilized here, removal of one item would have resulted in only a slight improvement of reliability. Removal of "My participation is important to the success of this organization" from the impact scale would have increased reliability by .03. Removal of "Working in this organization will help me achieve my future goals" from the meaningfulness scale would have increased reliability by .02 . Given the miniscule improvement by item removal, all items were retained in the analysis.

\section{Results and discussion \\ Bivarate correlations}

Bivariate correlations were conducted in order to measure the strength of the relationship between the three scales employed in the current analysis. The SelfAssessment of Resilience and Anxiety (SARA) scale was significantly correlated with both the GSE scale and both empowerment scales. The moderate positive correlation between SARA and GSE scales suggests that as resilience increases (scores on the SARA scale increase), scores measuring GSE increase, $r(44)=.41, p=.004$. This result supports our first hypothesis. Data, however, do not support our second hypothesis. Firstly, scores on both empowerment scales demonstrated a moderately significant negative correlation with SARA values (impact, $r(41)=-.41, p=.006$; meaningfulness, $r(39)=-.36, p=.02$ ). These results suggest that as resiliency scores increase, scores measuring the importance of workplace empowerment within the organization decrease. Secondly, no significant relationship was noted between the GSE and either workplace empowerment saliency scale (impact, $r(41)=-.25, p=.103$; meaningfulness, $r(39)=-.20, p=.22$ ).

\section{Analysis of variance (ANOVA)}

One-way ANOVAs were conducted to determine whether scores on each of the four scales were significantly different using four comparative variables: (1) gender, (2) nature of organization, (3) number of Palestinian governates individual staff members serve, and (4) number of years working in the humanitarian sector. Significant differences were noted between male and female respondents in SARA and workplace empowerment saliency scales. For the SARA, males indicated significantly higher mean scores $(M=51.4, \mathrm{SD}=13.7)$ than did females $(M=40.5, \mathrm{SD}=12.9), F(1,37)=6.6$, $p=.014$. On the other hand, female respondents reported significantly higher scores on the meaningfulness saliency scale $(M=8.48, \quad \mathrm{SD}=5.25)$ than did males $(M=4.5, \mathrm{SD}=4.85), \quad F(1,39)=6.19, p=.017$. Male and female respondents did not differ significantly in GSE scores or scores measuring impact saliency, $p>.10$. A final significant difference in impact saliency was found between participants by type of organization (international
NGO, Palestinian NGO, or government agency), $F(3,39)=$ $3.02, p=.041$. In this case, staff members of international NGOs $(M=20.54, \mathrm{SD}=9.98)$ and the one member of the organizational "other" category responded with significantly higher ratings on the impact scale than those working for Palestinian NGOs $(M=12.70, \mathrm{SD}=12.70)$. No other significant results were found in comparing scores based upon the nature of the organization, number of Palestinian governates serviced ( 1 vs. more than 1$)$, or number of years in humanitarian service (less than 5 vs. greater than 5 ), $p>.10$. Although these results indicate few differences between different categories of humanitarian workers working in Palestine, they do suggest a relative utility of these scales in assessing the group as a whole.

\section{Generalized self-efficacy, workplace empowerment saliency, and resiliency: implications for humanitarian training and practice}

Results of this quantitative pilot study indicate selfefficacy, components of workplace empowerment, and perceived resiliency are related. Firstly, our hypothesis that there would be a significant relationship between resiliency and generalized self-efficacy was supported with a significant positive correlation. Secondly, we predicted that there would be a positive relationship between resiliency and workplace empowerment. Counter to our hypothesis, a significant negative correlation was found between these two factors. Thirdly, a significant relationship was hypothesized between self-efficacy and workplace empowerment. Notably, no significant relationship was found between these two scales. In sum, as higher resiliency scores were reported, self-efficacy scores increased but less importance was placed on workplace empowerment (meaningfulness or impact). Higher self-efficacy scores did not impact self-reported scores of importance placed on workplace empowerment.

In a somewhat surprising twist, a negative relationship was found between resiliency and importance placed on workplace empowerment impact and meaningfulness). As self-reported resiliency scores increased, the importance participants placed on either meaningfulness of their position or the impact they may have on colleagues decreased. The nature of the quantitative survey precluded further explanation for any individual participant's answer. Expectations about workplace environment, employee empowerment, and management style vary among and within North American, Arab, and European cultures (Hajjawi 2012). Workers in particular settings may feel less inclined or limited in their ability to provide lateral-level (colleague-to-colleague) coaching or mentoring, particularly if management discourages such action. Finally, in Palestine, employment goals are commonly frustrated by military, economic, and political barriers imposed by Israel. Participants, therefore, may not feel the freedom to 
realize activities that support workplace impact or meaning. For example, permanent and temporary checkpoints decrease the ability to travel between offices to engage with organization members or to attend training workshops). On the other hand, Lopes Cardozo et al. (2005) found that among Kosovar Albanian workers, occupational support was less of a risk factor for depression and development of post-traumatic stress than in expatriate workers, due possibly to greater access to social or family support in the former. Future qualitative effort would complement the results discussed herein and provide valuable comparative figures.

Results presented here also indicate a gender-based difference in self-reported resiliency and aspects of workplace empowerment saliency. In the former, men reported higher scores than women, whereas in the latter, women placed more importance on meaningfulness. Differences between women and men regarding the saliency of impact, however, were not found. Applying an ecological framework (Bronfrenbrenner 1977), workers build support for resiliency or self-efficacy through direct interactions with other actors in their microsystem (family members, for example) or within their educational or workplace environment (mesosystem). On the other hand, institutional processes at the macrosystem level, such as cultural systems that perpetuate gender inequality in labor markets, may challenge resiliency or self-efficacy. Gender, in particular, is often a focus of attention at the macrosystem level. Feminist scholars have established a rich base of literature regarding the impact of the patriarchal system in Palestine and its effects on the social, political, and economic lives of women (Olmstead 2001; Haj 1992; Holt 2003). Nasser et al. (2010) found that although a majority of a sample of female Palestinian political activists supported equality in the workplace, it ranked lower in support than equality in access to healthcare, nutrition, and education. In the same sample, only a small minority of women (3 of 31) identified barriers associated with traditional gender roles (freedom of public movement or domestic division of labor, for example) as a social problem in their society. The respondents, instead, appeared to support maintenance of cultural mores concerning women's lives in the public sphere and division of labor vis-à-vis men, echoing similar observations made by Sholkamy (2010). The findings reported here and by previous authors, of course, exist within a framework of political, economic, and social oppression stemming, in large part, from the continued military occupation of the West Bank and the isolation of the Gaza Strip by Israel (Rought-Brooks et al. 2010).

Gender differences, therefore, may indicate key areas of future emphasis given that the Palestinian context of periodic violent conflict and military occupation already pressure workers' sense of resiliency and self-efficacy.
Palestinian women comprise a small minority of the Palestinian labor force. In 2012, participation of women in the Palestinian labor market amounted to $17.4 \%$ (PCBS 2013). These figures not only highlight the value and diversity of perspective women bring to the public sector but also the need for recognizing the potential for additional pressure brought upon women. Kuttab (2008) suggested that development agendas largely determined without local input serve to maintain the gender divide in Palestinian society. In these cases, women working for INGOs, as well as domestic Palestinian ones, may experience conflict between their own knowledge of social needs and those defined by their organization and foreign donors. This becomes a crucial point of discussion, as Fast (2006) previously found that Palestinian humanitarian workers are more likely to be concerned about the political impact of foreign aid than other "hidden agendas." This is not an insignificant point as women's varied roles in disaster response and recovery have previously been discussed in a variety of other international contexts (e.g., Enarson 1998; Enarson and Meyreles 2004; Mulyasari and Shaw 2013; Alam and Rahman 2014). Therefore, future research is needed to determine how the schism between personal knowledge and organizational agenda impacts female Palestinian humanitarian workers' sense of self-efficacy, resiliency, or workplace empowerment.

Data presented herein represent quantitative responses to scales measuring only four general concepts and are not necessarily related to clinical diagnoses of trauma, depression, or anxiety. Previous research suggests that concepts such as trauma or resilience may have different meanings in a Palestinian-specific context (Thabet et al. 2004; Rabaia et al. 2010). Veronese (2012), for example, noted that resilience was, in part, considered a personal characteristic among Palestinian humanitarian workers. The same authors also note differences regarding Western perspectives that emphasize individual experience and personal success whereas in Arab contexts, group membership and service is tied to personal well-being. Afana (2012) and colleagues (Afana et al. 2010) cautioned the uncritical application of the Western understanding of trauma to Palestinians as they may ignore locally derived expressions of distress and cultural meanings applied to traumatic events. In the future, additional qualitative analyses of questions concerning resilience, self-efficacy, and sub-factors of workplace empowerment may provide further detail to the preliminary interpretations offered herein. In addition, generalized scales, such as the ones utilized here, may also be combined with instruments designed to gather clinical or specific psychological measurement.

The study was also limited by the snowball methodology used to collect responses; thus, responses do not 
necessarily represent one organization, one level of worker, or one type of organization (non-governmental, international, or local government). Nor can it be confirmed that the sample included only national Palestinian (non-international) workers. To examine how individuals work and perceive success, measure impact, and build meaningfulness, attention should also be paid to specific organizational ecologies (Hobfall 2011). Additionally, recruitment of participants targeted a broad sampling of "helping profession" workers. In this case, the term "humanitarian worker" might encompass disaster relief volunteers, staff members of an economic development organization, or a faith-based charity sponsoring families or children. The results, therefore, cannot be generalized to all Palestinian humanitarian workers, nor one specific category of worker. Finally, the results are limited by the exclusion of valuable participants due to their lack of attachment to the network of participants built through the connections of the research team (Cohen and Arieli 2011). The results do, however, provide starting points for future comparisons with studies conducted on more specific categories of humanitarian workers.

McEntire et al. (2010: 55) states that "disaster vulnerability is composed of proneness to disaster as well as a limited ability to react when such events occur." Humanitarian organizations and their staff and volunteers form part of a complex socio-ecological system and lessons can be drawn from previous applications to disaster contexts (Edwards 1998; Weems and Overstreet 2008). Humanitarian actors in Palestine (disaster response as well as development organization staff) serve intermediary roles both in mitigating social, political, and environmental factors that make communities prone to disaster as well as providing response and recovery resources. Barriers imposed by Israel bar local Palestinian communities from developing sustainable emergency management plans, thereby increasing vulnerability. Vulnerability is also increased as political pressure is applied to Palestinian society during cyclical peace processes to normalize economic and political relations with Israel. In doing so, Palestinians are asked to implicitly endorse the very abnormal and restrictive security conditions under which they live within the borders of Palestine as ordinary and typical to forward peacebuilding efforts. In this case, mitigation of disaster vulnerability (including support of local humanitarian workers) should be undertaken so as to specifically label preparations made in response to social, economic, or political conditions that may be in contradiction to national obligations under international humanitarian law (IHL) or human rights law. In fact, emergency management is in a unique position to stand as a vehicle to expose vulnerabilities-man-made, technological, or natural-and provide a platform for strengthening of human security.
Recent climatological and geological research warns of increased risk of agricultural drought, earthquake, and water scarcity in the eastern Mediterranean and southwestern Asia in the near future (Al-Dabbeek and El-Kelani 2008; Al-Dabbeek 2010; Donat et al. 2014; Giorgi and Lionello, 2008; Philandras et al. 2011; Givati and Rosenfeld 2013; Lelieveld et al. 2012; Salehyan 2008). Combined with Israeli limitations made on capacity for maintenance or repair to public utility systems (for example, waste disposal, sewage treatment, and access to electricity), lack of comprehensive resource database construction and maintenance, and irregular training, these predictions of risk imply greater stress on local humanitarian workers in Palestine to service communities in need (Abd Rabou 2011; Alhindi and Al-Louh 2013; Al-Khatib et al. 2007; Barakat and Davis 1997; Erekat et al. 2013; Taha et al. 2014). Supporting workplace wellness [or creating caravan passageways; Hobfall (2011)] is, we argue, fundamental to maintaining the humanitarian supply chain during disasters, as well as supplementing individual, family, and community coping resources already stressed by chronic violence.

\section{Conclusion}

Previous research focusing on humanitarian workers has largely addressed the impact of exposure to violence and crisis stressors on expatriate workers (those not native to the area of service or whose service is temporary or short-term). Communities, particularly those facing external obstructions as in Palestine, benefit from a strong, local humanitarian workforce. Humanitarian and developmental organizations play vital roles by supporting community preparedness and hazard mitigation, as well as direct response and recovery services. In Palestine, these roles are played not only by emergency management, civil defense workers, and first responders but also by field workers engaged in existing development and community aid projects. Data obtained in the current study suggests a more complicated relationship between generalized self-efficacy, resiliency, and the importance of workplace empowerment than previously appreciated. We also highlight the need for future examination of differences between the experience of women and men in the non-profit workplace in Palestine, particularly in light of obstacles placed on economic, social, and political autonomy imposed by Israeli policy. There is also a need to more fully explore the experience of the local worker as compared to that of an expatriate. This study adds to our knowledge regarding the unique stresses on humanitarian workers and enhances a growing base of literature focused on local, national staff, and volunteers.

Competing interests

The authors declare that they have no competing interests. 


\section{Authors' contributions}

JBW completed literature reviews, carried out fieldwork, compiled survey instrument, performed statistical analysis, and drafted the manuscript. Al participated in translating survey instrument, recruiting participants, providing translations of participant responses, and assisting in data interpretation. All authors read and approved the final manuscript.

\section{Acknowledgement}

The authors would like to acknowledge each participant for the time and effort provided. Funding for various stages of the project were provided by Stockton University through the Provost Faculty Opportunity Fund and the Research and Professional Development grants program. The authors would like to also acknowledge the contributions of Dr. Melanie Hetzel-Riggin and Dr. Bridget Diamond-Welch, as well as Hammad Hamdan for valuable assistance with revision of manuscript draft stages and survey instrument translation, respectively.

\section{Received: 13 November 2015 Accepted: 25 February 2016} Published online: 07 July 2016

\section{References}

Abd Rabou AFN (2011) Environmental impacts associated with the Beit Lahia wastewater treatment plan, north Gaza Strip, Palestine. Middle East J Sci Res 7(5):746-757

Adams RE, Boscarino JA, Figley CR (2006) Compassion fatigue and psychological distress among social workers: a validation study. Am J Orthopsychiatry 76(1):103-108. doi:10.1037/0002-9432.76.1.103

Afana A (2012) Problems in applying diagnostic concepts of PTSD and trauma in the Middle East. Arab J Psychiatry 23(Supp):28-34

Afana A, Pederson D, Ronsbo H, Kirmayer LJ (2010) Endurance is to be shown at the first blow: social representations and reactions to traumatic experiences in the Gaza Strip. Traumatology 16(4):73-84. doi:10.1177/1534765610395663

Alam K, Rahman MH (2014) Women in natural disasters: a case study from southern coastal region of Bangladesh. Int J Disaster Risk Reduct 8:68-82

Al-Dabbeek J (2010) An assessment on disaster risk reduction in the occupied Palestinian territory. An-Najah Univ Res (N Sc) 24:1-46

Al-Dabbeek JN, El-Kelani RJ (2008) Rapid assessment of seismic vulnerability in Palestinian refugee camps. J Appl Sci 8(8):1371-1382

Alhajjar B (2014) Gaza nurses after war: are they traumatized? Procedia, S + BS 114:802-809. doi:10.1016/j.sbspro.2013.12.789

Alhindi Al, Al-Louh M (2013) Trends of intestinal parasites prevalence in the Gaza Strip, 1998-2007: the use of government health records. Turk J Med Sci 43:652-659

Al-Khatib IA, Arafat HA, Basheer T, Shawahneh H, Salahat A, Eid J, Ali W (2007) Trends and problems of solid waste management in developing countries: a case study in seven Palestinian districts. Waste Manag 27:1910-1919

BTselem (The Israeli Information Center for Human Rights in the Occupied Territories (2015) Restriction of movement., http://www.btselem.org/freedom_ of_movement/checkpoints_and_forbidden_roads. Accessed 15 June 2015

Balcik B, Beamon BM, Krejci C, Muramatsu KM, Ramirez M (2010) Coordination in humanitarian relief chains: practices, challenges and opportunities. Int J Prod Econ 126:22-34. doi:10.1016/j.jpe.2009.09.008

Bandura A (1977) Self-efficacy: toward a unifying theory of behavioral change. Psychol Rev 84(2):191-215

Barakat S, Davis I (1997) Disaster preparedness for Palestine. In: Zahlan AB (ed) The reconstruction of Palestine: issues, options, policies and strategies. Kegan Paul International, London, pp 287-303

Barnett SD, Connor KM, Davidson JRT (2001) Self-assessment of resilience and anxiety: psychometric properties. CNS Spectrums 6(10):854-857. doi:10.1017/ S1092852900001681

Baum N (2014) Work-family conflict among social workers, managers and policy makers in times of disaster. Br J Soc Work doi:10.1093/bjsw/bcu094

Bonnano GA (2008) Loss, trauma, and human resilience: have we underestimated the human capacity to thrive after extremely aversive events? Psychol Trauma S(1):101-113

Bonnan-White J, Hightower A, Issa A (2013) Of couscous and occupation: a case study of women's motivations to join and participate in Palestinian fair trade cooperatives. Agric Hum Values 30(3):337-350

Bronfrenbrenner U (1977) Toward an experimental ecology of human development. Am Psychol 32(7):513-531
Cohen A (2005) Administering the territories: an inquiry into the application of international humanitarian law by the IDF in the occupied territories. Isr Law Review 38(3):24-79

Cohen N, Arieli T (2011) Field research in conflict environments: methodological challenges and snowball sampling. J Peace Res 48(4):423-435

Cronin MS, Ryan DM, Brier D (2007) Support for staff working in disaster situations: a social work perspective. Int Soc Work 50(3):370-382. doi:10.1177/ 0020872807076050

da Costa SRA, Bandeira RAM, Mello LCBB, Campos VBG (2014) Humanitarian supply chain: an analysis of response operations to natural disasters. Eur J Transp Infrast 14(3):290-310

Darcy S, Reynolds J (2010) An enduring occupation: the status of the Gaza Strip from the perspective of international humanitarian law. J Conflict Sec L 15(2):211-243. doi:10.1093/jcsl/krq011

de Jong JTVM, Komproe IH, Van Ommeren M (2003) Common mental disorders in postconflict settings. Lancet 361:2128-2130

de Silva MW A (2009) Ethnicity, politics, and inequality: post-tsunami humanitarian aid delivery in Ampara District, Sri Lanka. Disasters 33(2):253-273

de Waal A (2010) The humanitarians' tragedy: escapable and inescapable cruelties. Disasters 34(S2):S130-S137

Department of Homeland Security (US) (2011) National Disaster Recovery Framework., http://www.fema.gov/media-library-data/20130726-1820-250455325/508_ndrf.pdf. Accessed 1 Sept 2015

Department of Homeland Security (US) (2013) National Response Framework., https://www.fema.gov/media-library-data/20130726-1914-25045-1246/ final_national_response_framework_20130501.pdf. Accessed 1 Sept 2015

Department of Homeland Security (US) (2015) National planning frameworks. http://www.fema.gov/national-planning-frameworks. Accessed 1 Sept 2015

Donat MG, Peterson TC, Brunet M, King AD, Almazroui M, Kolli RK, Boucher D, Al-Mulla AY, Nour AY, Aly AA, Nada TAA, Semawi MM, Al Dashti HA, Salhab TG, El Fadli KI, Muftah MK, Eida SD, Badi W, Driouech F, El Rhaz K, Abubaker MJY, Ghulam AS, Erayah AS, Mansour MB, Alabdouli WO, Al Dhanhani JS, Al Shekaili MN (2014) Changes in extreme temperature and precipitationin the Arab region: long-term trends and variability related to ENSO and NAO. Int J Climatol 34(3):581-592. doi:10.1002/joc.3707

Droege C (2007) The interplay between international humanitarian law and international human rights law in situations of armed conflict. Isr $\mathrm{L}$ Rev 40(2):2130-2355, www.ssrn.com/abstractid=1032149. Accessed 27 May 2014

Edwards MLK (1998) An interdisciplinary perspective on disasters and stress: the promise of an ecological framework. Sociol Forum 13(1):115-132

Ehrenreich JH, Elliott TL (2004) Managing stress in humanitarian aid workers: a survey of humanitarian aid agencies' psychosocial training and support of staff. Peace Confl 10(1):53-66

Enarson E (1998) Through women's eyes: a gendered research agenda for disaster social science. Disasters 22(2):157-173

Enarson E, Meyreles L (2004) International perspectives on gender and disaster: differences and possibilities. Int J Sociol Soc Pol 24(10/11):49-93

Erekat D, Nofal A, Zanon A, Abumiddain R, Abu-Hassanein Z, Linares-Rivas A, Phillipp B (2013) Rapid damage, loss and needs assessment of Winter Storm Alexa: a report by the Palestinian authority. World Bank Group, Washington, http://documents.worldbank.org/curated/en/2013/12/19756137/rapiddamage-loss-needs-assessment-winter-storm-alexa-report-palestinianauthority. Accessed 2 Nov 2014

Eriksson CB, Cardozo BL, Foy DW, Sabin M, Ager A, Snider L, Scholte WF, Kaiser R, Olff M, Rijnen B, Crawford CG, Zhu J, Simon W (2013) Predeployment mental health and trauma exposure of expatriate humanitarian aid workers: risk and resilience factors. Traumatol 19(1):41-48

Fast $L$ (2006) "Aid in a pressure cooker": humanitarian action in the occupied Palestinian territory. Humanitarian Agenda 2015 Case Study n.7. Feinstein International Center, Boston

Frymier AB, Shulman GM, Houser M (1996) The development of a learner empowerment measure. Commun Educ 45:181-199

Geneva Centre for the Democratic Control of Armed Forces (DCAF) (2008) The security sector legislation of the Palestinian National Authority., www.dcaf.ch/ content/download/35601/526419/file/final_EN.pdf civil defence law no. 3 palestine. Accessed 1 Sept 2015

Giacaman R, Husseini A, Gordon NH, Awartani F (2004) Imprints on the consciousness: the impact on Palestinian civilians of the Israeli Army invasion of West Bank towns. Eur J Public Health 14:286-290 
Giacaman R, Mataria A, Nguyen-Gillham V, Abu Safieh R, Stafanini A, Chatterji S (2007) Quality of life in the Palestinian context: an inquiry in war-like conditions. Health Policy 81:68-84

Giorgi F, Lionello P (2008) Climate change projections for the Mediterranean region. Glob Planet Change 63:90-104. doi:10.1016/j.gloplacha.2007.09.005

Givati A, Rosenfeld D (2013) The Arctic oscillation, climate change and the effects on precipitation in Israel. Atmos Res 132(133):114-124

Greenblatt K (2014) "Gate of the sun": applying human rights law in the occupied Palestinian territories in light of non-violence resistance and normalization. NW J Int'l Hum Rts 12(2):152-190

Gross AM (2007) Human proportions: are human rights the emperor's new clothes of the international law of occupation? Eur J Int'l L 18(1):1-35

Haj S (1992) Palestinian women and patriarchal relations. Signs 17(4):761-778, http://www.jstor.org/stable/3174534. Accessed 8 Mar 2009

Hajjawi O (2012) Autonomous motivation in Palestine through self-determination theory. Am J Bus Manag 1(3):133-139. doi:10.1111/j.2044-8325.2010.02016.x

Hilhorst D, Jansen BJ (2010) Humanitarian space as arena: a perspective on the everyday politics of aid. Dev Change 41(6):1117-1139

Hobfall SE (2011) Conservation of resource caravans and engaged settings. J Occup Organ Psychol 84:116-122

Hobfall SE, Johnson RJ, Canetti D, Palmieri PA, Hall BJ, Lavi I, Galea S (2012) Can people remain engaged and vigorous in the face of trauma? Palestinians in the West Bank and Gaza. Psychiatry 75(1):60-75

Holt M (2003) Palestinian women, violence, and the peace process. Dev Pract 13(2/3):223-238. doi:10.1080/0961452032000073206

Inhetveen K (2012) Translation challenges: qualitative interviewing in a multi-lingual field. Qual Sociol Rev 8(2):28-45, http://www.qualitativesociologyreview.org/ ENGNolume22/QSR_8_2_Inhetveen.pdf. Accessed 1 Nov 2015

International Committee of the Red Cross (2014) Gaza: ICRC condemns killing of Red Crescent volunteer., https://www.icrc.org/eng/resources/documents/ news-release/2014/07-25-gazavolunteer-killed.htm. Accessed 15 June 2015

Kanninen K, Punamäki R-L, Qouta S (2003) Adult attachment and emotiona responses to traumatic memories among Palestinian former political prisoners. Traumatol 9(3):127-154. doi:10.1177/153476560300900302. Accessed 23 Dec 2013

Khamis V (1993) Victims of the intifada: the psychosocial adjustment of the injured. Behav Med 19:93-101

Khamis V (2008) Post-traumatic stress and psychiatric disorders in Palestinian adolescents following intifada-related injuries. Soc Sci Med 67:1199-1207. doi:10.1016/j.socscimed.2008.06.013

Kleinfeld M (2007) Misreading the post-tsunami political landscape in Sri Lanka: the myth of humanitarian space. Space Policy 11(2):169-184

Kovacs G, Spens KM (2007) Humanitarian logistics in disaster relief operations. Int J Phys Dist Logist Manag 37(2):99-114. doi:10.1108/ 09600030710734820

Kretzmer D (2012) The law of belligerent occupation in the Supreme Court of Israel. Int Rev Red Cross 94(885):207-236. doi:10.1017/S1816383112000446

Kuttab E (2008) Palestinian women's organizations: global cooption and local contradiction. Cult Dyn 20(2):99-117. doi:10.1177/0921374008094283

Lelieveld J, Hadjinicolaou P, Kostopoulou E, Chenoweth J, El Maayar M, Giannakopoulos C, Hannides C, Lange MA, Tanarhte M, Tyrlis E, Xoplaki E (2012) Climate change and impacts in the Eastern Mediterranean and the Middle East. Clim Change 114:667-687. doi:10.1007/s10584-012-0418-4

Lopes Cardozo B, Holtz TH, Kaiser R, Gotway CA, Ghitis F, Toomey E, Salama P (2005) The mental health of expatriate and Kosovar Albanian humanitarian aid workers. Disasters 29(2):152-170. doi:10.1111/j.0361-3666.2005.00278.x

Lucchi $E$ (2010) Between war and peace: humanitarian assistance in violent urban settings. Disasters 34(4):973-995. doi:10.1111/j.0361-3666.2010.01178.x

Lunenburg FC (2011) Self-efficacy in the workplace: implications for motivation and performance. Int J Manag Bus Adm 14(1):1-6

Luszczynska A, Scholz U, Schwarzer R (2005) The generalized self-efficacy scale: multicultural validation studies. J Psychol 139(5):439-457

Ma'an News Agency (2013a) Missing persons found safe amid West Bank floods., http://www.maannews.com/Content.aspx?id=554624. Accessed 24 Mar 2015

Ma'an News Agency (2013b) 2 women found dead in West Bank floods., http://www.maannews.com/Content.aspx?id=554689. Accessed 24 Mar 2015

Ma'an News Agency (2013c) Man found dead in Tulkarem after 3-day hunt., http://www.maannews.com/Content.aspx?id=555048. Accessed 24 Mar 2015
Ma'an News Agency (2013d) Civil defense: 105 people treated during Gaza floods., http://www.maannews.com/Content.aspx?id=554887. Accessed 24 Mar 2015

Ma'an News Agency (2013e) Syrian refugees at mercy of winter storms on Lebanese coast., http://www.maannews.com/Content.aspx?id=554785. Accessed 24 Mar 2015

McCall M, Salama P (1999) Selection, training, and support of relief workers: an occupational health issue. BMJ 318:113-116

McEntire D, Crocker CG, Peters E (2010) Addressing vulnerability through an integrated approach. Int J Disaster Resilience Built Environ 1(1):50-64. doi:10.1108/17595901011026472

Ministry of Interior - State of Palestine (2014) Security Sector Strategic Plan, 2014 2016., http://www.lacs.ps/documentsShow.aspx?ATT_ID=13298. Accessed 1 Nov 2015

Mulyasari F, Shaw R (2013) Role of women as risk communicators to enhance disaster resilience of Bandung, Indonesia. Nat Hazards 69:2137-2160. doi:10.1007/s11069-013-0798-4

Musa SA, Hamid AARM (2008) Psychological problems among aid workers operating in Darfur. Soc Behav Pers 36(3):407-416

Nasser R, Barghouti F, Janan M (2010) Feminist attitudes and praxis among Palestinian women activists. Fem Form 22(3):146-175

Nilsson S, Sjoberg M, Kallenberg K, Larsson G (2011) Moral stress in international humanitarian aid and rescue operations: a grounded theory study. Ethics Behav 21(1):49-68

Office of the Coordination of Humanitarian Affairs (OCHA) - occupied Palestinian territory (2015a) Humanitarian Bulletin Monthly Report: May 2015., https:// www.ochaopt.org/documents/ocha_opt_the_humanitarian_monitor_2014_ 07_01_english.pdf. Accessed 1 Feb 2016

Office of the Coordination of Humanitarian Affairs (OCHA) - occupied Palestinian territory (2015b) Humanitarian Bulletin Monthly Report: December 2015. https://www.ochaopt.org/documents/ocha_opt_the_humanitarian_monitor_ 2016_01_05_english_dec.pdf. Accessed 1 Feb 2016

Office of the Coordination of Humanitarian Affaris (OCHA) - occupied Palestinian territory (2014) Humanitarian Bulletin Monthly Report: June-August 2014., https://www.ochaopt.org/documents/ocha_opt_the_humanitarian_monitor_ 2014_10_03_english.pdf

Olmstead J (2001) Men's work/women's work: employment, wages and occupational segregation in Bethlehem. In: Olmstead J (ed) The economics of women and work in the Middle East and North Africa, vol 4, Research in Middle East economics. Emerald Group Publishing Limited, Bingley, pp 151-174

Palestinian Central Bureau of Statistics (PCBS) (2013) Women and men in Palestine: issues and statistics, 2013. Palestine, Ramallah

Palestinian Non-Governmental Organizations Network (PNGO Net) (2015) Mission and vision., http://www.pngo.net/mission-vision/) - Accessed 7 Sept 2015

Palestinian Red Crescent Society (2014) Violations against PRCS' medical and humanitarian teams: annual report., https://www.palestinercs.org/reports/ Annual\%20report\%20English\%202014.pdf. Accessed 1 Feb 2016

Peltonen K, Qouta S, El Sarraj E, Punamäki R-L (2010) Military trauma and social development: the moderating and mediating roles of peer and sibling relations in mental health. Int J Behav Dev 34(6):554-563. doi:10.1177/ 0165025410368943

Philandras CM, Nastos PT, Kapsomenakis J, Douvis KC, Tselioudis G, Zerefos CS (2011) Long term precipitation trends and variability within the Mediterranean region. Nat Hazards Earth Syst Sci 11:3235-3250

Pigni A (2014) Building resilience and preventing burnout among aid workers in Palestine: a personal account of mindfulness based staff care. Intervention 12(2):231-239

Punamäki R-L, Kanninen K, Qouta S, El-Sarraj E (2002) The role of psychological defences in moderating between trauma and post-tramatic symptoms among Palestinian men. Int J Psychol 37(5):286-296. doi:10.1080/ 00207590244000133

Punamäki R-L, Komproe I, Qouta S, El-Masri M, de Jong JTVM (2005) The deterioration and mobilization effects of trauma on social support: childhood maltreatment and adulthood military violence in a Palestinian community sample. Child Abuse Negl 29:351-373. doi:10.1016/j.chiabu.2004.10.011

Qouta S, Punamäki R-L, El Sarraj E (2008) Child development and family mental health in war and military violence: the Palestinian experience. Int J Behav Dev 32(4):310-321

Rabaia Y, Giacaman R, Nguyen-Gillham V (2010) Violence and adolescent mental health in the occupied Palestinian territory: a contextual approach. Asia Pac J Public Health 22(3):216S-221S 
Ramon S, Campbell J, Lindsay J, McCrystal P, Baidoun N (2006) The impact of political conflict on social work: experiences from Northern Ireland, Israel and Palestine. Br J Soc Work 36:435-450. doi:10.1093/bjsw/bcl009

Rought-Brooks H, Duaibis S, Hussein S (2010) Palestinian women: caught in the cross fire between occupation and patriarchy. Fem Form 22(3):124-145

Roy S (2004) The Palestinian-Israeli conflict and Palestinian socioeconomic decline: a place denied. Int J Pol C S 17(3):365-403, http://www.jstor.org/ stable/20007687. Accessed 15 June 2015

Rubenstein LS, Bittle MD (2010) Responsibility for protection of medical workers and facilities in armed conflict. Lancet 375:329-340

Rytter MJH, Kjaelgaard AL, Brønnum-Hansen H, Helweg-Larsen K (2006) Effects of an armed conflict on access to emergency health care in Palestinian West Bank: systemic collection of data in emergency departments. BMJ 332(7550): $1122-1124$

Salehyan I (2008) From climate change to conflict? No consensus yet. J Peace Res 45(3):315-326. doi:10.1177/0022343308088812

Scholz U, Dona BG, Sud S, Schwarzer R (2002) Is general self-efficacy a universal construct? Psychometric findings from 25 countries. Eur J Psychol Assess 18(3):242-251

Schwarzer R, Jerusalem M (1995) Generalized Self-Efficacy scale. In J Weinman, S Wright, M Johnston, Measures in health psychology: a user's portfolio. Causal and control beliefs. Windsor, England: NFER-NELSON 35-37

Schwarzer R, Hallum S (2008) Perceived teacher self-efficacy as a predictor of job stress and burnout: mediation analysis. Appl Psychol 57:152-171. doi:10.1111/ j.1464-0597.2008.00359.x

Shah SA, Garland E, Katz C (2007) Secondary traumatic stress: prevalence in humanitarian aid workers in India. Traumatol 13(1):59-70

Shalhoub-Kevorkian N (2015) Security theology, surveillance and the politics of fear. Cambridge University Press, Cambridge

Sholkamy H (2010) Power, politics and development in the Arab context: or how can rearing chicks change patriarchy? Development 53(2):254-258

Simo G, Bies AL (2007) The role of nonprofits in disaster response: an expanded model of cross-sector collaboration. Public Adm Rev 61(s1):125-142. doi:10.1111/j.1540-6210.2007.00821.x

Sumathipala A, Murray J (2000) New approach to translating instruments for cross-cultural research: a combined qualitative and quantitative approach for translation and consensus generation. Int J Meth Psych Res 9(2):87-95

Suparamaniam N, Dekker S (2003) Paradoxes of power: the separation of knowledge and authority in international relief work. Disaster Prev Manag 12(4):312-318

Taha S, Rabi A, Touzi S (2014) Regional assessment of past drought and flood episodes and their management in selected SWIM-SM PCS. Tunisia, Jordan and Palestine, http://www.swim-sm.eu/files/SWIM-SM_1_3_3_1DroughtFloodAssessment.pdf. Accessed 27 Apr 2015

Thabet AAM, Tischler V, Vostanis P (2004) Maltreatment and coping strategies among male adolescents living in the Gaza Strip. Child Abuse Negl 28:77-91

Thomas K, Velthouse B (1990) Cognitive elements of empowerment" an "interpretive" model of intrinsic task motivation. Acad Manage Rev 15:666-681

United Nations International Strategy for Disaster Reduction (2009) UNISDR Terminology on Disaster Risk Reduction, http://www.unisdr.org/files/7817_ UNISDRTerminologyEnglish.pdf

United Nations (2012) Resolution adopted by the General Assembly: 67/19 Status of Palestine in the United Nations., http://palestineun.org/wp-content/ uploads/2013/08/67-19-Status-of-Palestine.pdf. Accessed 1 Nov 2015

United Nations Disaster Assessment Coordination Team (2014) UNDAC Disaster response preparedness mission to the State of Palestine., http://www. ochaopt.org/documents/undac mission_report.pdf

United Nations Office for Disaster Risk Reduction (2015) Background paper-proposed updated terminology on disaster risk reduction: a technical review., http://www.preventionweb.net/files/45462 backgoundpaperonterminologyaugust20.pdf. Accessed 1 Nov 2015

Vergara JA, Gardner D (2011) Stressors and psychological wellbeing in local humanitarian workers in Colombia. J Manage Psychol 26(6):500-507. doi:10.1108/02683941111154365

Veronese G (2012) Self-perceptions of well-being in professional helpers and volunteers operating in war contexts. J Health Psychol 18(7):911-925. doi:10.1177/1359105312457804

Weems CF, Overstreet S (2008) Child and adolescent mental health research in the context of Hurricane Katrina: an ecological needs-based perspective and introduction to the special section. J Clin Child Adolesc Psychol 37(3):487-494. doi:10.1080/15374410802148251

\section{Submit your manuscript to a SpringerOpen ${ }^{\circ}$ journal and benefit from:}

- Convenient online submission

- Rigorous peer review

- Immediate publication on acceptance

- Open access: articles freely available online

- High visibility within the field

- Retaining the copyright to your article

Submit your next manuscript at $\gg$ springeropen.com 